\title{
O SACRIFÍCIO ANIMAL EM RITUAIS RELIGIOSOS OU CRENÇAS
}

\author{
THE ANIMAL SACRIFICE IN RELIGIOUS RITUALS OR BELIEFS
}

\author{
Tereza Rodrigues Vieira ${ }^{1}$ \\ Camilo Henrique Silva ${ }^{2}$
}

\section{RESUMO}

Com fundamento em pesquisa bibliográfica, este artigo tem por escopo a análise do sacrifício de animais não humanos em rituais religiosos ou crenças praticadas em território brasileiro. Trazendo subsídios morais, éticos e legais, essa realidade nacional será discutida a fim de se chegar a resposta de qual bem deverá ser protegido e garantido: a liberdade religiosa ou a vida dos animais não humanos?

Palavras-chave: Direito Animal; Bioética; Religião; Animais; Princípios Constitucionais.

\begin{abstract}
Based on a bibliographical research, this article has the scope of the analysis of the sacrifice of nonhuman animals in religious rituals or beliefs practiced in Brazilian territory. By bringing moral, ethical and legal support, this national reality will be discussed in order to arrive at an answer of which good should be protected and guaranteed: religious freedom or the life of nonhuman animals?
\end{abstract}

Keywords: Animal Rights; Bioethics; Religion; Animals; Constitutional Principles.

\footnotetext{
${ }^{1}$ Pós-Doutora em Direito pela Université de Montreal. Professora no Mestrado em Direito Processual e Cidadania na Universidade Paranaense, UNIPAR. São Paulo (Brasil). E-mail: terezavieira@uol.com.br

2 Doutorando em Educação pela PUC-Rio. Mestre em Direito Processual e Cidadania pela UNIPAR. Rio de Janeiro (Brasil). E-mail: E-mail: camilo.henrique@ufms.br.
} 


\section{INTRODUÇÃO}

Pautada pelas novas descobertas da ciência, a relação entre homens e animais tem sido discutida sob novos fundamentos, no intuito de ultrapassar o paradigma dominante antropocêntrico, num viés para a defesa e proteção dos animais.

Argumentos éticos, morais, filosóficos, religiosos e legais são alçados para a regulação da convivência entre homens e animais. Dentro dessa perspectiva, a utilização do animal pelo homem passa a ser confrontada, na busca de sua limitação, e porque não, exclusão.

Em nome da fé, algumas religiões realizam rituais de sacrifício animal. Esse trabalho aborda, num primeiro momento, as principais religiões no mundo e sua relação com os animais. Em seguida, passa a dialogar sobre o tema específico do sacrifício de animais em rituais ou cultos, sob o ponto de vista legal e moral, com base no ordenamento jurídico brasileiro.

Em um primeiro olhar, os rituais de sacrifício animal se assemelham a práticas arcaicas, produzidas no início da civilização humana, contudo, sua presença persiste ainda no século XXI. O debate sobre tal prática é atual e necessário. De um lado, temos religiões que mantêm esse costume milenar como um de seus pilares e fundamentos de fé, de outro, temos algumas resgatando tais procedimentos, num retorno às suas origens sagradas.

Esse trabalho, desenvolvido com supedâneo em pesquisa bibliográfica, sob o ângulo moral, ético e legal, tem por escopo a análise do abate de animais não humanos em rituais religiosos em território brasileiro, prática viva e comum a ocorrer diariamente, sem qualquer embaraço, constrangimento ou questionamento, afinal, a lei garante a liberdade religiosa, porém, protege os animais não humanos.

Diante disso, inúmeras são as reflexões bioéticas oriundas desse polêmico assunto, tais como: o que deve prevalecer: a liberdade da prática religiosa ou a vida dos animais? Se animais não têm crenças ou religiões por que são oferecidos em rituais de sacrifício? É justo pagar promessas com sacrifício de outrem? Há diferença entre matar um animal para churrasco entre amigos ou matá-lo em ritual religioso? Há diferença entre matar um animal em um altar de sacrifício de uma religião de matriz africana e matar um peru na data em que se comemora o nascimento de Cristo? É justo morrer ignorando os motivos da morte? Por que algumas religiões veneram os animais e outras os sacrificam? Podemos limitar a crença do indivíduo? O animal pode ser usado em um espetáculo de sacrifício, pois não foi criado à imagem e semelhança do Criador? Animais são ou não dignos de compaixão? 


\section{A RELIGIÃO, OS ANIMAIS E OS SACRIFÍCIOS}

\subsection{Hinduísmo}

Entendem os hinduístas que, por acreditarem na reencarnação dos seres humanos, qualquer ato de agressão praticado a um ser vivo pode ter como consequência reencarnar em uma espécie inferior, como de um animal, pois será indigno de renascer como humano. Dessa forma, a violência independe se é "contra seres humanos ou contra os de outras espécies. Ela contamina não quem a sofre, mas quem a pratica. A referência moral é o sujeito, não o objeto afetado por suas ações" (FELIPE, 2007, p. 204).

O grau de evolução é o que diferencia os seres humanos dos animais. Para os hinduístas, é proibido ferir ou matar qualquer ser vivo. Exemplo disso, o "Código Védico adverte que quem matar e comer uma vaca renascerá como vaca e será morto tantas vezes quantos são os pêlos do animal morto" (DIAS, 2000, p. 137). Para o hinduísmo, se "não podemos criar, não temos o direito de matar nenhuma entidade viva" (DIAS, 2000, p. 138). A violência contra os animais torna o espírito impuro.

Para o hinduísmo, matar se refere tão somente ao organismo vivo e não ao espírito da criatura. Assim, os seres humanos e os animais apenas têm sua morte carnal, mas nunca do espírito. Portanto, a morte de um animal, mesmo em sacrifício, apenas extermina seu exterior, sua embalagem, mas nunca o essencial, seu espírito (BOWKER, 1986, p. 7-8 apud FELIPE, 2007, p. 203).

No distrito de Bara, sul do Nepal, ao avesso das considerações sagradas, a cada 5 anos ocorre uma cerimônia no templo hinduísta Gadhimai, onde são sacrificados animais para a honra da deusa do poder, Gadhimai. O ritual de sacrifício acontece há mais de dois séculos, e no último evento, em 2009, cerca de 500 mil animais foram mortos, entre búfalos, cabras e galinhas. Diante da pressão e comoção mundial, Motilal Prasad, administrador do templo Gadhimai, decretou o fim do sacrifício de animais, sob o argumento da senciência animal (SCHEER, 2015).

Entre os hinduístas, não há fundamento ou espaço para os seres humanos terem deveres morais diretos com os animais não humanos (FELIPE, 2007, p. 204). A defesa ou preocupação com os animais ocorre de maneira indireta, pois na busca pela evolução espiritual, o ser humano guiar-se-á pelo princípio da não-violência, direcionada para os homens ou os animais. 


\subsection{Jainismo}

Jainistas acreditam "que todas as criaturas têm uma identidade entre si, como forma de uma única realidade divina e cósmica” (DIAS, 2000, p. 139). Tanto é assim, que o jainismo entende existir apenas "duas classes de seres: os conscientes (todos os seres vivos) e os nãoconscientes (a matéria, o tempo e o espaço)" (FELIPE, 2007, p. 202).

Na classe dos seres conscientes, estes se distinguem pelo número de sentidos, e em razão de sua complexidade, são classificados em diferentes e hierarquizados grupos. Por serem dotados de seis sentidos (ver, ouvir, degustar, cheirar, tocar e pensar), os humanos, aves e alguns animais estão no topo da escala, diferenciando-se dos demais seres pela complexidade mental, por terem energia, espírito e consciência (FELIPE, 2007, p. 206-207).

Os jainistas creem que a formação do homem não está atrelada na sua forma biológica, mas sim, às suas ações aos outros homens e aos animais (FELIPE, 2007, p. 207). Diante desse princípio, o jainismo condena qualquer ato de violência praticado a um ser vivo, pois afeta o espírito, rompe a unidade da vida (DIAS, 2000, p. 139).

Para o jainismo, todo ser vivo ama estar vivo, logo, qualquer ato de violência praticado contra um ser sensível prejudica o próprio autor, impedindo sua evolução espiritual (CHAPPLE, 1986, p. 216 apud FELIPE, 2007, p. 231). Diante dessa postura, os jainistas "recusam-se a tomar parte em qualquer ritual de sacrifício animal” (FELIPE, 2007, p. 203).

Existem santuários jainistas onde todos circulam livremente, fato que comprova a interação entre os seres vivos - homens e animais. No "povoado de Deshnoke, no templo Karni Mata, os ratos passeiam livremente enquanto os devotos oram. Os sacerdotes do templo e os ratos comem nas mesmas tigelas e bebem água no mesmo lugar" (DIAS, 2000, p. 139).

Mahatma Gandhi foi um dos jainistas mais conhecidos no mundo ocidental. Líder político do século XX, assassinado em 1948, clamava "piedade a todos os animais, lembrando que essas indefesas criaturas, vítimas da maldade e da tirania humana, não têm força para nos resistir" (LEVAI, 2004, p. 22).

Destarte, para os “jainistas la dieta vegetariana es la expresión lógica del seguimiento de lo que constituye su primer voto: la doctrina de la ahimsâ o ausencia de la voluntad de matar, de herir o causar daño a ningún ser vivo" (LORA, 2003, p. 186). Assim, os jainistas "pautam sua vida na não-violência, são vegetarianos e reverenciam a natureza ao extremo" (DIAS, 2000, p. 138). 
Cumpre aqui lembrar a grande contribuição do Hospital Jain para as aves em Nova Deli. Fundado em 1956 por jainistas, referido hospital de três andares, pode acomodar 10.000 aves, possuindo inclusive unidade de terapia intensiva e laboratório de pesquisa. Diariamente, chegam 60 a 70 aves enfermas para tratamento (NAKOS, 2010).

O jainismo declara a luta contra maus-tratos e crueldade, não aceita qualquer tipo de violência e utilização desses seres para a ritualização religiosa ou alimentação.

\subsection{Budismo}

Prega o budismo, sobre o ciclo vital, a ocorrência de renascimentos, e, em cada um deles, o ser vivo deve buscar a evolução espiritual, desapegando-se materialmente. Dessa forma, pode "esse renascimento dar-se com relação à consciência do próprio ser, ao descobrir um caminho de luz e de vida, que pode ou não o levar a outro corpo" (NOGUEIRA, 2012, p. 9). Caso venha a "encarnar na forma animal, o ser recebe uma punição específica por ter cometido alguma falta irreparável na vida anterior" (FELIPE, 2007, p. 208).

No tocante ao sacrifício de animais, os budistas rejeitam tal ritual, "pois entendem que a morte intempestiva impede os seres animados, humanos e não-humanos, de realizar o fim para o qual nascem" (FELIPE, 2007, p. 202). Apesar da rejeição ao sacrifício, há relatos na literatura budista do autossacrifício, ocorrendo tanto de animais em favor dos homens ou de homens em favor dos animais (CHAPPLE, 1986, p. 220 apud FELIPE, 2007, p. 209).

Importante aqui mencionar um posicionamento de Buda, quando este dialoga com Kutanga sobre o sacrifício em rituais, na passagem de Pitkas:

\footnotetext{
Quem sacrifica aos deuses seus maus desejos e vis paixões compreende a inutilidade de banhar em sangue animais inocentes as aras do altar [...] qualquer pessoa pode tirar a vida, mas é incapaz de dar. [...] O homem implora a misericórdia dos deuses e não tem misericórdia com os animais, para os quais ele é como um deus. [...] Ninguém pode purificar seu espírito com sangue, pois se os deuses são bons, não lhes pode ser agradável, e se são maus, este não basta para suborná-los. (SING, s.d., p. 169-170 apud DIAS, 2000, p. 140).
}

Com supedâneo na não-violência e no respeito a todas as formas de vida, o budismo repudia a violência contra os animais, em especial, no tocante ao sacrifício desses indivíduos. Para essa tradição religiosa, a "divindade é vista como se manifestando em todos os seres vivos. De fato, a realização da divindade dentro de si é quase sempre o objetivo da prática espiritual dentro dessas tradições” (WHITE JR., 1967 apud JAMIESON, 2010, p. 46). 
Segundo essa cultura oriental, o respeito pelos seres vivos, animais humanos ou não, está na base de sua doutrina, pregando ao homem sua evolução espiritual, baseada no princípio da não-violência.

\subsection{Islamismo}

Reconhece o islamismo, na comparação entre homens e animais, no aspecto físico, a superioridade destes. O homem leva vantagem na vontade espiritual (taquwah), determinante para a consciência humana, a fim de distinguir o pensamento consciente, fazendo assim, o melhor uso da liberdade. Portanto, “a condição humana, criada e habilitada para diferenciar entre o mal e a virtude, exerce a liberdade de escolha, algo impossível aos demais animais, incapazes de fazer distinções morais" (MASRI, 1986, p. 176 apud FELIPE, 2007, p. 219-220).

O sacrifício de animais integra a cultura islâmica, oportunidade em que milhares de animais são sacrificados para celebrar o ato realizado por Abraão no monte Moriá (CERQUEIRA, 2014). Atualmente não se tem relatos de rituais de sacrifícios religiosos de animais.

Acrescenta-se ainda que a utilização de animais na alimentação é permitida na religião islâmica, porém, o abate segue normas religiosas. Essa prática, chamada de hallal, consiste na jugulação do animal ainda consciente. A jugulação, segundo Levai (2004, p. 85-86), ocorre da seguinte forma:

O boi, ao ser derrubado ou contido, sofre uma incisão transversal do pescoço, cortandose-lhe o pelo, os músculos, o esôfago, a traqueia, as artérias, as carótidas e as veias jugulares, enquanto o ritual sagrado - cabeça do animal voltada para Meca e oração a Alá - é cumprido, conforme os milenares preceitos do Corão.

O que ocorre é um verdadeiro sacrifício, apesar de o abate não ser para fins religiosos, mas para alimento, vez que o animal é morto de acordo com normas seculares. Tais preceitos acabam por imprimir sofrimento desnecessário ao animal, pois este não recebe qualquer anestesia ou meio paliativo para não sentir dor, sendo um ato cruel, que não segue qualquer regra de abate humanitário.

Logo, o islamismo não reconhece qualquer direito direto aos animais. Dessa maneira, autorizada está a utilização dos animais como alimentos pelos seres humanos, desde que o abate ocorra de acordo com a tradição religiosa, por meio do hallal. 


\subsection{Judaísmo}

Com relação aos animais, o judaísmo não traz regras para promover seu bem-estar (FELIPE, 2007, p. 213). Ao contrário, desde sua origem, o judaísmo, "estabelece que todas as espécies animais foram criadas para benefício humano" (BLEICH, 1986, p. 106 apud FELIPE, 2007, p. 216). Portanto, para os judeus, os animais não possuem qualquer interesse, pois foram criados por Deus para servirem ao homem.

Para os judeus, não há qualquer dever direto do ser humano para com os animais. $\mathrm{O}$ judaísmo prescreve como "dever do homem para consigo mesmo, o dever de impedir que seu ser se torne veículo de práticas cruéis", como por exemplo, maus-tratos aos animais (FELIPE, 2007, p. 227). Com tal prescrição, a crueldade aos animais é evitada para o benefício direto do homem, a fim de evitar seu embrutecimento.

Soma-se a isso, o judaísmo aceita a utilização de animais em diversas atividades, inclusive, para a alimentação. Nesse ponto, quando o animal servir de alimento, defende que tal prática seja sem dor e sofrimento. Tal rito é chamado de shehitah, o abate indolor (FELIPE, 2007, p. 216). O método judaico aponta para uma morte sem dor, porém, atualmente existem práticas mais humanas, "por exemplo, a utilização de uma pistola pneumática, que deixa o animal insensível” (SINGER, 2010, p. 226).

Sobre o ritual de abate para consumo, os rabinos ortodoxos não são unânimes no abrandamento da prática. De acordo com Singer (2010, p. 227), os rabinos, "na Suécia, Noruega e na Suíça, aceitaram, sem exceção, a legislação que exige o atordoamento para o abate ritualístico".

Quanto aos sacrifícios de animais em rituais religiosos, tal prática era comum na antiguidade, como forma para agradar a Javeh. Segundo Felipe (2003, p. 24), na verdade, os rituais de abate e oferenda tinham como função principal o suprimento de carne como alimento para os sacerdotes e funcionários dos templos, que funcionavam como verdadeiros abatedouros. As oferendas à Javeh, por meio do abate ritualizado, tinham como intuito manter a mesa dos sacerdotes abastecida com carne, garantindo a boa vida mesmo em períodos de escassez.

A prática, comum no passado, ressurge em Israel, na cidade de Jerusalém, pelos judeus ortodoxos. Por meio do resgate da tradição de Leviim, uma tribo bíblica de Levi dedicada aos cuidados dos templos, os judeus têm praticado, nos últimos anos, diversos sacrifícios de animais em nome da religião. Segundo o rabino Yehuda Glick, o ritual está sendo feito de acordo com a 
bíblia e a lei judaica, em um altar construído exclusivamente para o abate de cabras, mortas ao som de orações e cantos (JUDEUS, 2014).

Em síntese, para o judaísmo os animais não possuem qualquer interesse, liberdade ou integridade física. Os deveres dos homens em relação aos animais são apenas indiretos, especificamente, garantir e preservar o animal como bens, patrimônio. Quanto ao sacrifício, apesar de comum em tempos remotos, seus praticantes ortodoxos buscam a retomada de tal ofício, demonstrando claramente sua despreocupação com os direitos dos animais.

\subsection{Cristianismo}

Para o Cristianismo, somente a vida do homem é sagrada, ao possuir uma alma imortal. Na Bíblia, mesmo no Novo Testamento, não há "qualquer injunção contra a crueldade para com os animais, ou qualquer recomendação para que seus interesses sejam levados em conta" (SINGER, 2010, p. 278). Aliás, como levar em conta o interesse de indivíduos sem alma, criados exclusivamente para o benefício do homem?

Santo Agostinho, influente teólogo cristão, apoiado sob o argumento de os animais não humanos serem destituídos dos atributos do pensamento e da escolha, afirma ser natural o homem servir-se de seus corpos, não sendo pecado matá-los (GORDILHO, 2008, p. 22). Para Santo Agostinho, Jesus desobrigou os homens de qualquer comprometimento com os animais, descabendo, portanto, amoldar seu comportamento a esses seres às leis morais existentes (SINGER, 2010, p. 279).

No mesmo sentido, São Tomás de Aquino não considera pecado qualquer ato de crueldade ou maus-tratos aos animais não humanos. Para Singer (2010, p. 270), essa posição tinha como pano de fundo os interesses humanos na exploração dos animais, fato mascarado pelas ideias religiosas, morais e metafísicas. Nesse ponto, importante acrescentar o pensamento sobre os animais deste teólogo cristão:

\footnotetext{
Además, insiste santo Tomás, 'los animales brutos y las plantas no tienen vida racional por la cual puedan obrar por si mismos sino que siempre actúan como movidos por otros, por cierto impulso natural. $\mathrm{Y}$ esto es señal de que son naturalmente esclavos y han sido acomodados para los usos de otros'. (LORA, 2003, p. 51).
}

Por conseguinte, percebe-se que a insensibilidade cristã com a situação dos animais não humanos no mundo é extrema. Nesse sentido, o Papa Pio IX, em meados do século XIX, proibiu a criação de sociedades protetoras dos animais em Roma. (SINGER, 2010, p. 284-285; MORRIS, 
1990, p. 38). Para os cristãos a compaixão humana tem um limite, raso por sinal, e qualquer utilização para causas "não importantes" resulta em seu esgotamento para as consagradas no livro sagrado.

Apenas em 1988 a Igreja Católica aponta para a preocupação com as causas ecológicas. $\mathrm{Na}$ “encíclica Solicitudo Rei Socialis [Sobre a solicitude social], o papa João Paulo II apela para que o desenvolvimento humano inclua "respeito pelos seres que fazem parte do mundo natural"' (SINGER, 2010, p. 285-286).

Em um posicionamento mais recente, em 18 de junho de 2015, a Igreja Católica, por intermédio do Papa Francisco, apresentou ao mundo encíclica voltada ao meio ambiente, conclamando a responsabilidade de todos pelo planeta. Nesse documento, a Igreja Católica não se posiciona abertamente à defesa e proteção dos animais, mas, de certo modo, mitiga o dogma antropocêntrico de Deus ter criado a Terra para exploração e dominação sem limites do homem, ao dizer que:

Se é verdade que nós, cristãos, algumas vezes interpretamos de forma incorreta as Escrituras, hoje devemos decididamente rejeitar que, do fato de ser criados à imagem de Deus e do mandato de dominar a terra, se deduza um domínio absoluto sobre as outras criaturas. É importante ler os textos bíblicos no seu contexto, com uma justa hermenêutica, e lembrar que nos convidam a «cultivar e guardar»o jardim do mundo (cf. Gn 2, 15). Enquanto «cultivar» quer dizer lavrar ou trabalhar um terreno, «guardar» significa proteger, cuidar, preservar, velar. Isto implica uma relação de reciprocidade responsável entre o ser humano e a natureza. (CARTA, 2015, p. 53-54).

Portanto, "a Igreja Católica não admite que os animais tenham direitos morais, e, assim, não considera que os seres humanos tenham quaisquer deveres em relação a eles" (GAFFNEY, 1986, p. 168 apud FELIPE, 2007, p. 239). Em 1897, a Igreja Católica, por meio do Dicionário Católico, afirma que os animais não possuem direitos, sendo, inclusive, "legal matá-los, ou infligir dor a eles, por qualquer fim bom e razoável [...] até com o objetivo de recreação" (MORRIS, 1990, p. 38-39).

Esse posicionamento é reafirmado na encíclica ao meio ambiente de junho de 2015, ao pregar a supremacia do ser humano sobre tudo o que existe na Terra. Como diz Papa Francisco, os seres vivos não são iguais, tendo o homem "valor peculiar". Quanto à crueldade com outros seres vivos, a encíclica adverte que tal prática acaba por repercutir no tratamento com os outros seres humanos. Por fim, condena aqueles que lutam em favor dos animais enquanto há seres humanos em miséria (CARTA, 2015, p. 70-72).

Tal fato, como aponta Gray (2011, p. 64), ocorre porque para os cristãos, apenas a vida dos seres humanos tem um sentido, o que falta aos outros animais. Por terem recebido tal dádiva 
de Deus, por terem sido criados à sua imagem, apenas o homem tem o direito de escolher livremente os rumos de sua vida.

Para White Jr. (1967 apud JAMIESON, 2010, p. 45), o toque especial, o diferenciador do cristianismo frente às demais religiões do mundo é ser a mais antropocêntrica, inspirada na crença de Deus ter-se tornado homem na forma de Jesus.

Atualmente, o Cristianismo não mais pratica rituais de sacrifício animal para seu Deus, apesar de a Bíblia estar repleta de tais passagens.

\subsection{Africanas}

A cultura religiosa africana remonta a três mil anos, sendo preservadas suas práticas pelos novos adeptos (CHUAHY, 2006, p. 71).

As religiões mais conhecidas no Brasil são o candomblé e a umbanda. Os rituais de práticas ofertatórias aos orixás e divindades são comuns, incluindo flores, ervas, frutos, alimentos, velas e o sacrifício de animais não humanos.

A umbanda, de todas as religiões africanas, é a única a não sacrificar animais em seus rituais de oferenda. Para isso, se utiliza de outros produtos, como ervas, frutos, flores. O não sacrifício de animais não impede a realização dos cultos e rituais pela umbanda, pois ao substituir pelas ervas e frutos, por exemplo, evidencia e estima o respeito e a "união religiosa com as divindades e os espíritos da natureza ou que se servem dela para auxiliarem os encarnados" (AZEVEDO; OLIVEIRA, 2014, p. 6).

No candomblé, os animais são considerados como oferendas aos orixás. Conforme apontam Azevedo e Oliveira (2014, p. 5-6), as oferendas servem como alimentos aos orixás (amalás), assim, são ofertadas partes dos animais sacrificados ("forças" ou "axé"), cruas ou não. As partes dos animais ofertadas são as patas, asas, cabeça, cauda, coração, pulmão e moela; as demais não possuem valor como oferenda.

Sobre o sacrifício e a oferenda, Vallado (2008, p. 57-89), Cabrera (2004, p. 164-171) e Campolim (2014) trazem maiores detalhes sobre o ritual:

\section{O sacrifício}

Acontece apenas diante dos membros da comunidade de santo e envolve no mínimo dois animais: um, de duas patas, para Exu, e outro, de quatro patas, macho ou fêmea, dependendo do sexo do orixá a ser homenageado. Quem realiza o sacrifício é o ogã axogum, um iniciado no candomblé especialmente preparado para isso. Os bichos são mortos com um golpe na nuca. Depois, a cabeça e os membros são cortados fora e o animal sacrificado vai sangrar até a última gota antes de ser destinado à oferenda. 


\begin{abstract}
A oferenda
Depois do sacrifício, a moela, o fígado, o coração, os pés, as asas e a cabeça são separados e oferecidos ao orixá homenageado num vaso de barro, chamado alguidar. $\mathrm{O}$ sangue, recolhido numa quartinha de cerâmica (espécie de moringa), é derramado sobre o assentamento do santo, ou seja, o local onde ficam seus objetos e símbolos. As partes restantes são destinadas ao jantar oferecido aos orixás, ainda à tarde, e aos participantes, ao final da festa pública, à noite. (CAMPOLIM, 2014).
\end{abstract}

O sacrifício de animais para o candomblé faz parte de seus rituais, cultos e festividades dos terreiros. Para Cerqueira (2014), o "sacrifício desses animais possui um investimento simbólico e litúrgico imprescindível para a teogonia e liturgias próprias do contexto religioso". Os animais abatidos para os rituais são os geralmente utilizados para a alimentação humana, como as aves (pombas e galináceos), chamadas de "dois pés", e os ovinos, suínos, bovinos e caprinos, chamados de "quatro pés".

Acredita-se na imprescindibilidade dos rituais de sacrifício para a sobrevivência da religião, pois segundo a crença, as entidades espirituais devem ser alimentadas, senão morrem. Nesse sentido, Vida (2007, p. 298) aponta "um provérbio Yorubá que diz que quando uma entidade espiritual não é alimentada ela morre, ela deixa de existir".

Vale destacar que, a relação de algumas religiões africanas com os animais não humanos é meramente utilitarista, servem apenas como alimento. Para essas crenças, os animais foram feitos para alimentar os seres humanos e as entidades espirituais. Ante sua utilidade, os animais devem ser sacrificados em rituais específicos, ofertados aos orixás para sua alimentação. Em troca do alimento, os orixás devem realizar os pedidos dos fieis.

\title{
3 BRASIL: ENTRE A LIBERDADE RELIGIOSA E A PROTEÇÃO DOS ANIMAIS
}

O Brasil, constituído como Estado laico, consagra a liberdade religiosa de seu povo, formado pela diversidade cultural, tendo nesse aspecto, uma de suas grandezas. O constituinte, ao pensar a Constituição Federal, buscou garantir o direito à liberdade religiosa, possibilitando a todo cidadão, a livre escolha, permanência e retirada de credos. Em seu artigo $5^{\circ}$, inciso VI, a Carta Magna diz ser "inviolável a liberdade de consciência e de crença, sendo assegurado o livre exercício dos cultos religiosos e garantida, na forma da lei, a proteção aos locais de culto e às suas liturgias" (BRASIL, 2014a).

Quando se fala em religião, entende-se "o complexo de princípios que dirigem os pensamentos, ações e adoração do homem para com Deus, acaba por compreender a crença, o 
dogma, a moral, a liturgia e o culto" (MORAES, 2007, p. 41). Portanto, tal liberdade, como assevera Silva (2010, p. 248), “compreende três formas de expressão (três liberdades): (a) a liberdade de crença; (b) a liberdade de culto; (c) e a liberdade de organização religiosa".

Dessa maneira, o cidadão, no Brasil, possui direito de escolher sua religião, de aderir a uma seita religiosa, de mudar de credo, de ser descrente, ateu, agnóstico, ou mesmo de não aderir a qualquer religião (SILVA, 2010, p. 249). Dentro de tantas opções, a lei impede o constrangimento de qualquer pessoa à religião escolhida, como por exemplo, ser obrigado a renunciar sua fé, o que representaria "o desrespeito à diversidade democrática de ideias, filosofias e a própria diversidade espiritual" (MORAES, 2007, p. 41).

Assegurado o direito à escolha de uma religião, a lei, sabidamente, garante a liberdade de culto. Para Silva, (2010, p. 249), a religião se exterioriza pelo culto, compreendido na prática de ritos, "com suas cerimônias, manifestações, reuniões, fidelidades aos hábitos, às tradições”.

Destarte, o constituinte brasileiro estabelece, como extensão ao direito à liberdade, o direito à crença, à religião, aos cultos. Dessa maneira, garante ao cidadão a livre escolha de sua religião, de sua fé. Em contrapartida, proíbe o Estado de interferir nessa relação, e mais, o conclama a proteger tal liberdade, preservando os locais de culto, suas liturgias (BRANDÃO, 2007, p. 313), bem como, impedir qualquer discriminação ao cidadão, seja pública ou particular, em razão de sua religião.

No pertinente à fauna, Levai (2004, p. 48) afirma que o sistema constitucional brasileiro prioriza a chamada "função ecológica da fauna", em detrimento dos animais de maneira individual. Estes têm suporte legal no $\S 1^{\circ}$, do artigo 225, da Carta Magna, ao prever tratamento ético, vedado quaisquer atos de crueldade. Todavia, apesar da proibição de maus-tratos, a Constituição brasileira concebe o animal não humano como coisa, bem móvel, recurso ambiental.

Com a nova sistemática constitucional, tem-se como princípio a preservação da vida animal, carreando ao Poder Público o dever de zelar por esse interesse, sendo ilegal a morte desses indivíduos sem qualquer justificativa aceitável (MACHADO, 2010, p. 844). Diante desses preceitos legais, destaca-se, portanto, como conclusão lógica, o direito à vida dos animais não humanos. Nesse aspecto, a Constituição Federal segue a Declaração Universal dos Direitos dos Animais, que em seu artigo 11, alínea a, define como biocídio, um delito contra a vida, matar um animal sem necessidade (DIAS, 2000, p. 336).

No plano infraconstitucional, a proteção dos animais não humanos contra os atos de crueldade praticados pelos seres humanos está definida na Lei $\mathrm{n}^{\circ} 9.605$, de 12 de fevereiro de 
1998, que dispõe sobre as sanções penais e administrativas derivadas de condutas e atividades lesivas ao meio ambiente.

Em seu artigo 32, a Lei 9.605/98 trata da prática de abuso e maus-tratos contra animais não humanos, sejam domésticos, domesticados, nativos ou exóticos. A pena é pequena, ao prever detenção de três meses a um ano, e multa ao agente. No mesmo delito incorre quem realizar experiência cruel ou dolorosa em animal vivo, mesmo para fins educacionais ou científicos, se existirem meios alternativos. Por fim, o parágrafo segundo da norma aumenta a pena de um sexto a um terço caso o animal morra (BRASIL, 2014b).

Apesar da pena irrisória, foi importante a lei ter abrangido os "animais domésticos e domesticados, em seu artigo 32, o qual transformou as antigas contravenções (artigo 64 do Decreto-lei $\mathrm{n}^{\mathrm{o}}$ 3688/41), em crimes" (TINOCO; CORREIA, 2010, p. 178). Portanto, a "criminalização veio em boa hora. As contravenções não tiveram maior efetividade, fato que se constata facilmente pela ausência de precedentes judiciais" (FREITAS; FREITAS, 2012, p. 113).

Dessa forma, ao contrário do pensamento antropocêntrico, a normativa legal definida no artigo 32 da Lei dos Crimes Ambientais não foi elaborada para a preservação psíquica do ser humano, mas sim, para a proteção dos animais não humanos. Assim, a norma infraconstitucional ao regular o estampado no inciso VII, do parágrafo primeiro, do artigo 225 , da Constituição Federal, mostra à sociedade sua intolerância com os maus-tratos aos animais.

Do exposto, delineado de um lado o direito à liberdade religiosa e do outro o direito à vida do animal não humano, com a proibição de atos cruéis, este trabalho se volta à discussão proposta, analisar, sob o ângulo legal e moral, o confronto desses interesses, quando o sacrifício de animais não humanos faz parte dos cultos, rituais e práticas religiosas.

Logo, questiona-se: Qual interesse deve prevalecer: a vida ou a religião? Qual é mais importante? É justo morrer pela religião de outrem? Enfim, diante do impasse, a solução seria óbvia se a vida em jogo fosse de um ser humano. Mas, no caso, a vida é de um animal e, diante desse fato, muitos ainda se perguntam: a vida do animal tem valor em si mesmo? Devemos proteger os animais ou eles foram criados para serem mortos?

Nesse impasse, diante de opiniões diversas, as soluções, basicamente, possuem dois lados. Uma favorável ao direito do ser humano em poder cultuar sua religião na forma como ela é, com seus hábitos, cultos e liturgias, independentemente de sacrificar ou não animais. A outra, disposta a proteção à vida do animal não humano, no rompimento do pensamento antropocêntrico dominante em nossa sociedade, limitando, assim, não o direito à fé de cada um, mas apenas os rituais de adoração. 
Em uma visão antropocêntrica, Fiorillo (2009, p. 189) caracteriza a crueldade contra o animal quando "não tiver por finalidade proporcionar ao homem uma sadia qualidade de vida ou, na hipótese de estar presente esse propósito, os meios empregados não forem os absolutamente necessários à atividade". Ao caminhar com este pensamento, as práticas religiosas de sacrifício animal devem prevalecer, pois, trata-se de uma conduta "cultural na medida em que traz a identificação de valores de uma região ou população" (FIORILLO, 2009, p. 190). No caso em questão, os valores bíblicos do judaísmo e/ou as práticas rituais do candomblé justificam a prática.

Em defesa da prática de sacrifício cometida pelas religiões africanas, Cerqueira (2014) baseia-se na doutrina religiosa e na Instrução Normativa $n^{\circ} 3$, de 17 de janeiro de 2000, da Secretaria de Defesa Agropecuária, do Ministério da Agricultura, Pecuária e Abastecimento, que aprovou o Regulamento Técnico de Métodos de Insensibilização para Abate Humanitário de Animais de Açougue. Como a finalidade do sacrifício é alimentar às entidades espirituais, destaca o item 11.3 da norma administrativa, que concede o abate na forma e normas dos preceitos religiosos, quando destinados à comunidade religiosa.

Contudo, tal fundamento apresentado por Cerqueira (2014) não prevalece para o caso dos sacrifícios realizados nos terreiros de candomblé ou em templos judaicos. A norma em comento tem seu âmbito de aplicação nos "estabelecimentos industriais que realizam o abate dos animais de açougue" (BRASIL, 2014c). De pronto, templos e locais de culto não se enquadram no conceito de "estabelecimentos industriais", o que por si só desnatura a fundamentação. Outrossim, o abate desses animais pela indústria, em tese, possibilita uma "boa morte", sem sofrimento desnecessário, por ser realizada por profissionais habilitados, munidos de equipamentos adequados, diferentemente quando ocorre durante os rituais, nos quais a preocupação é com o culto e não com a oferenda.

Ao concluírem pela prevalência da religião à vida, Azevedo e Oliveira (2014, p. 14) afirmam que a prática do sacrifício animal em rituais não afronta a ordem social, a moral ou os bons costumes, em razão da singularidade religiosa de cada indivíduo. Nessa esteira, sob a égide do ordenamento jurídico brasileiro, Cerqueira (2014) entende inexistir "qualquer objeção ao abate religioso, de sorte que especulações neste sentido devem ser creditadas a desinformação, a ignorância, à improvisação ou em muitos casos a uma indisfarçável discriminação religiosa".

Posição semelhante é a de Carvalho e Câmara (2014), ao afirmarem que o sacrifício animal em práticas religiosas possui respaldo jurídico e antropológico, porém, sua condenação 
social, pelos não praticantes, ocorre pelo discurso da intolerância, pela falta de dever ético, de valor moral, de respeito à diferença, à pessoa alheia. Tadvald (2014, p. 143) também acolhe o discurso do ódio, da intolerância e do preconceito para fundamentar as críticas sofridas às religiões praticantes do sacrifício animal, em especial, as de matrizes africanas.

A defesa dos rituais de sacrifício é a adoção pura e simples do pensamento antropocêntrico, em sua esfera especista, ao dizer que os sacrificados são apenas "animais", e com eles se faz o que quer, do jeito que quiser, pois não merecem qualquer cuidado, compaixão ou direito. Aliás, pensamento firmado no mundo ocidental por meio das religiões monoteístas, como islamismo, judaísmo e cristianismo, ao "destruíram por completo a imagem sacralizada dos animais existentes no oriente, transformando sua importância em um mero utilitarismo a serviço do homem" (NOGUEIRA, 2012, p. 11).

Ao debater a questão sob a visão antropocêntrica, especista, não há sequer conflito, basta alegar, como faz Fiorillo (2009, p. 185), que a "finalidade da fauna é determinada diante do benefício que a sua utilização trará ao ser humano", e o problema estará solucionado. O debate ultrapassa a visão egoísta do ser humano, buscando enxergar no outro, em um animal, diferente na forma e aparência, mas com sentimentos próximos, de dor, medo, angústia, fome, sede, frio, e que também luta, como o homem, por sua vida e liberdade.

A condição de ser senciente dos animais, mamíferos e aves, por exemplo, está confirmada pela ciência, por meio de inúmeros estudos científicos. Dessa forma, como aponta Regan (2006, p. 66), impossível negar a essas espécies de animais não humanos a condição de sujeitos-de-uma-vida. As espécies sencientes possuem interesses comuns, são conscientes do mundo, sentem dor e prazer, assim como os humanos.

Os interesses e modo de vida de humanos e animais não humanos são diferentes. Contudo, trata-se "de puro senso comum o reconhecimento de que, por trás daqueles olhos, nossos companheiros animais são criaturas psicológicas complexas, e não menos sujeitosde-uma-vida do que nós" (REGAN, 2006, p. 66-67). Todo o animal não humano tem um valor em si mesmo, um valor intrínseco, residindo aí sua dignidade, por ter interesse em sua existência e no que lhe acontece. Desse modo, passa a ter o direito de não ser agredido, de não ter sua dignidade violada, seja física ou psíquica (FEIJÓ, 2008, p. 142-143).

Como aponta Bulos (2010, p. 555), o direito à livre escolha de religião é legítimo, porém, a liberdade nos cultos e rituais não é ilimitada, devendo estar em acordo com a lei, e nesse caso, ela proíbe a prática de crueldade contra os animais, inclusive, com a sua criminalização. No mesmo sentido, Moraes (2007, p. 43) afirma que a liberdade de religião não é 
absoluta, não sendo permitidos, em seus cultos, liturgias e hábitos, atos atentatórios à lei, sob pena de responsabilização.

Todavia, também existem argumentos utilizados para a defesa do sacrifício de animais nos rituais religiosos, os quais consideram essa prática um pilar das religiões que os cultuam, e por serem milenares, são imprescindíveis para sua própria existência (CARVALHO; CÂMARA, 2014). Contudo, tal argumento não se sustenta, e para isso há um exemplo forte e esclarecedor, inclusive dentro das religiões de matriz africanas, no caso, a umbanda.

Dessa forma, ao contrário dos que advogam a manutenção de prática obsoleta e descompassada de fundamento moral ou legal, a insistência do abate ritualístico de animais precisa ser revista. Aliás, como aponta Lourenço (2007, p. 273), tal discussão não se insere "num contexto de ataque à religião como instituição e sim a um de seus aspectos materiais, que pode e deve ser aprimorado".

Ainda na busca pela manutenção de tal prática, mas com o apoio do Direito, Segato (apud TADVALD, 2014, p. 144), argumenta que a análise jurídica deve ser feita "através da [ética da] 'libertação', nos posicionando no lugar de quem está sofrendo, por exclusão, martírio ou qualquer coisa que o valha, em cada momento histórico". Assim, o intérprete deve buscar a visão e percepção de mundo do outro, para, dessa forma, pensar e agir conforme suas convicções, e não simplesmente por uma visão egoísta, própria.

Diante dos fatos e argumentos, a liberdade religiosa deve ser garantida, contudo, seus cultos, liturgias, tradições e manifestações devem ter limites, respeitando os demais interesses consagrados no Direito e na moral. Portanto, a liberdade religiosa não é absoluta, como nenhum outro direito.

Nessa esteira, no conflito constitucional do direito à vida e o direito à religião, deve prevalecer àquela, pois os rituais de sacrifício submetem os animais a atos de crueldade (LEVAI, 2004, p. 87). Atos esses descabidos e sem propósitos, perfeitamente ajustados a nova ordem social, moral e legal, sem qualquer prejuízo às religiões.

Logo, os religiosos, ao matarem um animal em cultos e rituais, cometem o crime do artigo 32 da Lei n. 9.605/98, devendo responder por tal ilícito. Portanto, comete crime, agindo com dolo direto, quem participa do "sacrifício' de animais em seitas ritualísticas (magia negra, candomblé, quimbanda, etc.)" (LEVAI, 2004, p. 40).

A norma do artigo $5^{\circ}$, inciso VI, da Constituição Federal, como afirma Brandão (2007, p. 317) não se trata de excludente de antijuridicidade para a prática do crime entabulado no artigo 
32 da Lei n. 9.605/98. Ao contrário, o direito à religião, a uma fé, não deve ser aceito como fundamento para a prática de ilícito, seja contra um ser humano ou contra animais não humanos.

Logo, "a lei deve servir para proteger os mais fracos, tirando dos mais fortes o direito de vilipendiar aqueles que se encontram em condições adversas” (FELIPE, 2007, p. 257), no caso em debate, os animais não humanos. Dessa forma, o respeito e o direito aos sistemas religiosos não pode impedir sua avaliação legal (LOURENÇO, 2007, p. 273), em especial, quando massacram seres vulneráveis em nome da fé, que ao contrário da crença dos praticantes, não se doam voluntariamente ao sacrifício, sendo abatidos à força e ao arrepio da lei.

Sobre isso, ao falar das religiões e animais, Regan (2006, p. 86), com fundamento no amor, na ética e na fé, conclama a todos, independentemente do credo, a se unirem e lutarem pela defesa dos animais não humanos, extirpando de nosso mundo toda a dor, sofrimento e exploração que passam esses seres vulneráveis.

Dessa forma, ao contrário do impregnado pela cultura industrial da exploração, os direitos dos animais podem ser defendidos por todas as culturas, credos e religiões, bastando a cada um, rever sua relação com os animais, transformando-as em uma ética de respeito e amor.

\section{CONSIDERAÇÕES FINAIS}

No Brasil, a prática de rituais religiosos a contemplar o sacrifício de animais não humanos é comum nas culturas do candomblé, ocorrendo diuturnamente por todo o território nacional. Tal hábito é fundamentado no direito constitucional à liberdade de religião. Porém, de outro lado, temos a proibição de atos de crueldade aos animais não humanos, também uma previsão constitucional.

Diante desse conflito de interesses, vozes debatem, com opiniões favoráveis a ambos os lados. Aos que pregam a prevalência do sacrifício animal, seu fundamento básico é o antropocentrismo, em que o animal tem apenas utilidade aos desígnios humanos, nesse caso, ser oferenda aos deuses por meio de seu sacrifício durante ritual religioso. Para esse pensamento, todo e qualquer motivo de proibição dessa prática tem base no preconceito religioso, na intolerância do homem para com seu irmão. Logo, para essa corrente, de clara ideologia especista, inexiste ao animal qualquer interesse ou direito.

Aos que defendem o outro lado, a lei constitucional garante a integridade física e a vida dos animais não humanos, sendo, terminantemente proibidas práticas cruéis, como seu sacrifício 
em rituais religiosos. Nesse sentido, a lei infraconstitucional criminaliza essa prática, cabendo aos agentes responderem pela conduta delituosa. Tal entendimento ultrapassa a simples visão antropocêntrica, numa busca pela valorização do animal pelo que representa ao meio natural, e não somente aos caprichos do homem.

O conflito de interesses não pode ser encarado apenas pela visão do interesse humano, antropocêntrico e especista, mas sim, com a ampliação da abrangência moral aos animais não humanos. Aliás, a lei brasileira garante aos animais sua vida contra atos de crueldade, e neste caso, abrange a proibição de sua morte em terreiros e altares espalhados pelo Brasil.

A limitação dos caprichos e desejos do homem frente ao interesse da vida, da liberdade e da dignidade dos animais está fundamentada no direito, na moral e na própria religião. No direito, pela proibição de práticas cruéis. Na moral, pela consideração aos interesses daqueles que sofrem, numa ética da compaixão e respeito. Na religião, pelos princípios da não-violência, da conduta de amor e respeito ao próximo, mesmo sendo esse próximo um animal não humano, diferente do homem na aparência, mas semelhante nos sentimentos, no desejo de viver, de ser livre. Porém, a visão antropocêntrica impede o reconhecimento do não uso de animais nos rituais religiosos ou comemorativos.

Portanto, o multiculturalismo presente na população brasileira, com suas diversas culturas e crenças, precisa se reeducar, para enxergar os animais não humanos como companheiros de uma existência sadia e de respeito no planeta Terra, abandonando, assim, o pensamento antropocêntrico e especista destrutivo, egoísta e segregacionista, em que ao ser humano é possível tudo, inclusive, matar em nome da fé.

\section{REFERÊNCIAS}

AZEVEDO, A. O.; OLIVEIRA, M. M. F. Liberdade de culto e religião - sacrifício ritual de animais. Revista Eletrônica Inter Lex, v. 02, p. 02-16, 2013. Disponível em: <http://net.esbam.edu.br/ojs/ojs-2.3.4/index.php/lex/article/view/154>. Acesso em: 30 ago. 2014.

BRANDÃO, G. J. Uso de Animais em Rituais Religiosos e Legislação Brasileira em Vigor. Revista Brasileira de Direito Animal. Ano 2, n. 2, jan./jun. 2007, p. 309-317. Salvador: Evolução, 2007.

BRASIL. Constituição da República Federativa do Brasil (1988). Diário Oficial [da] República Federativa do Brasil, Brasília, DF, 5 outubro 1988. Disponível em: 
<http://www.planalto.gov.br/ccivil_03/constituicao/constituicaocompilado.htm>. Acesso em: 30 set. 2014a.

. Lei $\mathrm{n}^{\mathrm{o}}$ 9.605, de 12 de fevereiro de 1998. Dispõe sobre as sanções penais e administrativas derivadas de condutas e atividades lesivas ao meio ambiente, e dá outras providências. Diário Oficial [da] República Federativa do Brasil, Brasília, DF, 13 fev. 1998. Disponível em: <http://www.planalto.gov.br/ccivil_03/leis/19605.htm>. Acesso em: 30 set. 2014b.

Ministério da Agricultura e do Abastecimento. Instrução normativa $\mathbf{n}^{\mathbf{0}}$ 3, de 17 de janeiro de 2000. Regulamento técnico de métodos de insensibilização para o abate humanitário de animais de açougue. Disponível em: 〈http://www.agricultura.gov.br/>. Acesso em: 01 out. 2014c.

BULOS, U. L. Curso de direito constitucional. 5. ed. São Paulo: Saraiva, 2010.

CABRERA, L. Iemanjá \& Oxum: Iniciações, Ialorixás e Olorixás. Tradução Carlos Eugênio Marcondes de Moura. São Paulo: Editora da Universidade de São Paulo, 2004.

CAMPOLIM, S. Candomblé no Brasil: orixás, tradições, festas e costumes. Super Interessante. Janeiro 1995. Disponível em: <http://super.abril.com.br/religiao/candomble-brasil-orixastradicoes-festas-costumes-441075.shtml> Acesso em: 1 jun. 2012.

CARTA Encíclica Laudato Si’ do Santo Padre Francisco sobre o cuidado da casa comum. Disponível em:

<http://w2.vatican.va/content/dam/francesco/pdf/encyclicals/documents/papafrancesco_20150524_enciclica-laudato-si_po.pdf>. Acesso em: 30 jul. 2015.

CARVAlHO, A. B. G.; CÂMARA, D. C. C. Multiculturalismo e colisão de direitos: A liberdade religiosa e o sacrifício de animais em rituais religiosos de matriz africana. Jus Navigandi, Teresina, ano 19, n. 3928, 3 abr. 2014. Disponível em: <http://jus.com.br/artigos/27281>. Acesso em: 29 set. 2014.

CERQUEIRA, M. S. Liberdade de culto x imolação de animais: a efetividade de um direito fundamental. Defensoria Pública do Estado de Sergipe, 09 abril 2013. Disponível em: <http://www.defensoria.se.gov.br/?p=2891>. Acesso em: 30 set. 2014.

CHUAHY, R. O extermínio dos animais. Rio de Janeiro: Zit, 2006.

DIAS, E. C. A tutela jurídica dos animais. Belo Horizonte: Mandamentos, 2000.

FEIJÓ, A. G. S. A dignidade e o animal não-humano. In: MOLINARO, C. A. et al (Org.). A dignidade e os direitos fundamentais para além dos humanos: uma discussão necessária. Belo Horizonte: Fórum, 2008. p. 127-143.

FELIPE, S. T. Ética e experimentação animal: fundamentos abolicionistas. Florianópolis: UFSC, 2007. 
Por uma questão de princípios: alcance e limites da ética de Peter Singer em defesa dos animais. Florianópolis: Fundação Boiteux, 2003.

FIORILLO, C. A. P. Curso de direito ambiental brasileiro. 10. ed. São Paulo: Saraiva, 2009.

FREITAS, V. P.; FREITAS, G. P. Crimes contra a natureza. 9. ed. São Paulo: Revista dos Tribunais, 2012.

GORDILHO, H. J. S. Abolicionismo animal. Salvador: Evolução, 2008.

GRAY, J. Cachorros de palha: reflexões sobre humanos e outros animais. Tradução Maria Lucia de Oliveira. 7. ed. Rio de Janeiro: Record, 2011.

JAMIESON, D. Ética e meio ambiente: uma introdução. Tradução André Luiz de Alvarenga. São Paulo: Senac, 2010.

JUDEUS ortodoxos retomam em Jerusalém rituais de sacrifício. Paulopes, 04 abril 2013. Disponível em: <http://www.paulopes.com.br/2013/04/judeus-ortodoxos-retomam-rituais-desacrificio.html\#.VCswSWddX4Y>. Acesso em: 30 set. 2014.

LEVAI, L. F. Direito dos Animais. 2. ed. Campos do Jordão: Mantiqueira, 2004.

LORA, P. Justicia para lós animales: la ética más allá de la humanidad. Madri: Alianza Editorial, 2003.

LOURENÇO, D. B. A liberdade de culto e o direito dos animais (parte 2). Revista Brasileira de Direito Animal. Ano 2, n. 3, jul./dez. 2007, p. 271-288. Salvador: Evolução, 2007.

MACHADO, P. A. L. Direito ambiental brasileiro. 18. ed. São Paulo: Malheiros, 2010.

MORAES, A. de. Direito constitucional. 21. ed. São Paulo: Atlas, 2007.

MORRIS, D. O contrato animal. Tradução Lucia Simonini. Rio de Janeiro: Record, 1990.

NAKOS, J. Le jainisme et les animaux. Les Cahiers Antispéciste, n. 42, Março de 2010.

NOGUEIRA, V. M. D. Direitos fundamentais dos animais: a construção jurídica de uma titularidade para além dos seres humanos. Belo Horizonte: Arraes Editores, 2012.

REGAN, T. Jaulas Vazias: encarando o desafio dos direitos animais. Tradução Regina Rheda. Porto Alegre: Lugano, 2006.

SILVA, J. A. Curso de direito constitucional positivo. 33. ed. São Paulo: Malheiros, 2010.

SINGER, P. Libertação Animal. Tradução Marly Winckler; Marcelo Brandão Cipolla. São Paulo: WMF Martins Fontes, 2010.

TADVALD, M. Direito litúrgico, direito legal: a polêmica em torno do sacrifício ritual de animais nas religiões afro-gaúchas. Revista Caminhos, Goiânia, v. 5, n. 1, p. 129-147, jan./jun. 
2007. Disponível em: <http://seer.ucg.br/index.php/caminhos/article/view/443/368>. Acesso em: 15 ago. 2014.

TINOCO, I. A. P.; CORREIA, M. L. A. Análise crítica sobre a declaração universal dos direitos dos animais. Revista Brasileira de Direito Animal. Ano 6, n. 7, jul./dez 2010, p. 169-195. Salvador: Evolução, 2010.

VALLADO, A. Iemanjá, a grande mãe africana do Brasil. 1. ed. Rio de Janeiro: Pallas, 2008. 